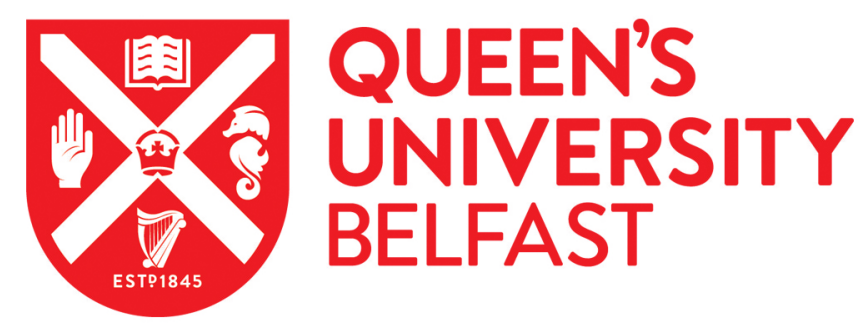

\title{
Development and pharmacokinetics of a combination vaginal ring for sustained release of dapivirine and the protein microbicide 5P12-
} RANTES

McBride, J. W., Malcolm, R. K., Dias, N., Cameron, D., Offord, R. E., Hartley, O., Kett, V. L., Devlin, B., \& Boyd, P. (2019). Development and pharmacokinetics of a combination vaginal ring for sustained release of dapivirine and the protein microbicide 5P12-RANTES. International Journal of Pharmaceutics, 564, 207-213.

https://doi.org/10.1016/j.ijpharm.2019.04.040

\section{Published in:}

International Journal of Pharmaceutics

\section{Document Version:}

Peer reviewed version

Queen's University Belfast - Research Portal:

Link to publication record in Queen's University Belfast Research Portal

\author{
Publisher rights \\ Copyright 2019 Elsevier. \\ This manuscript is distributed under a Creative Commons Attribution-NonCommercial-NoDerivs License \\ (https://creativecommons.org/licenses/by-nc-nd/4.0/), which permits distribution and reproduction for non-commercial purposes, provided the \\ author and source are cited.
}

\section{General rights}

Copyright for the publications made accessible via the Queen's University Belfast Research Portal is retained by the author(s) and / or other copyright owners and it is a condition of accessing these publications that users recognise and abide by the legal requirements associated with these rights.

Take down policy

The Research Portal is Queen's institutional repository that provides access to Queen's research output. Every effort has been made to ensure that content in the Research Portal does not infringe any person's rights, or applicable UK laws. If you discover content in the Research Portal that you believe breaches copyright or violates any law, please contact openaccess@qub.ac.uk. 


\section{Accepted Manuscript}

Development and pharmacokinetics of a combination vaginal ring for sustained release of dapivirine and the protein microbicide 5P12-RANTES

John W. McBride, R. Karl Malcolm, Nicola Dias, David Cameron, Robin E. Offord, Oliver Hartley, Vicky L. Kett, Brid Devlin, Peter Boyd

PII: S0378-5173(19)30302-3

DOI: https://doi.org/10.1016/j.ijpharm.2019.04.040

Reference: IJP 18288

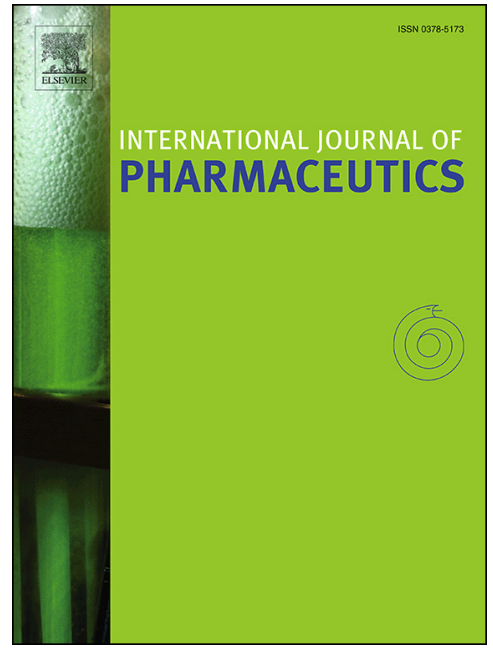

To appear in:

International Journal of Pharmaceutics

Received Date:

14 March 2019

Revised Date:

12 April 2019

Accepted Date:

13 April 2019

Please cite this article as: J.W. McBride, R. Karl Malcolm, N. Dias, D. Cameron, R.E. Offord, O. Hartley, V.L. Kett, B. Devlin, P. Boyd, Development and pharmacokinetics of a combination vaginal ring for sustained release of dapivirine and the protein microbicide 5P12-RANTES, International Journal of Pharmaceutics (2019), doi: https:// doi.org/10.1016/j.ijpharm.2019.04.040

This is a PDF file of an unedited manuscript that has been accepted for publication. As a service to our customers we are providing this early version of the manuscript. The manuscript will undergo copyediting, typesetting, and review of the resulting proof before it is published in its final form. Please note that during the production process errors may be discovered which could affect the content, and all legal disclaimers that apply to the journal pertain. 
Development and pharmacokinetics of a combination vaginal ring for sustained release of dapivirine and the protein microbicide 5P12RANTES

John W. McBridea, R. Karl Malcolma, Nicola Dias ${ }^{b}$, David Cameron', Robin E. Offordc, Oliver Hartleyc,d, Vicky L. Ketta, Brid Devline, Peter Boyda*

a School of Pharmacy, Queen's University Belfast, Belfast BT9 7BL, UK

${ }^{b}$ Envigo, Huntingdon, Cambridgeshire, UK

c Mintaka Foundation for Medical Research, Geneva, Switzerland

${ }^{d}$ Department of Pathology and Immunology, Faculty of Medicine, University of Geneva, Geneva, Switzerland

e International Partnership for Microbicides, Silver Spring, Maryland 20910, USA

*Corresponding author. Tel:+44 (0)2890972623 E-mail: p.boyd@qub.ac.uk 


\section{Abstract}

The past fifteen years have witnessed a resurgence of interest in vaginal ring technologies for drug delivery applications, mostly driven by the impetus for development of vaginallyadministered antiretroviral microbicides to help reduce the high acquisition rates for human immunodeficiency virus (HIV) among Sub-Saharan African women. Currently, the lead candidate microbicide is a 28-day silicone elastomer vaginal ring releasing dapivirine (Ring004), an experimental non-nucleoside reverse transcriptase inhibitor. The ring was tested in two pivotal Phase III clinical studies in 2016 and is currently undergoing review by the European Medicines Agency. Recently, we described a new type of silicone elastomer vaginal ring offering sustained release of the protein molecule 5P12-RANTES, a potent experimental chemokine analogue that potently blocks the HIV CCR5 coreceptor. Building on our previous work, here we report the preclinical development of a new combination vaginal ring that offers sustained release of both 5P12-RANTES and dapivirine, in which the 5P12-RANTES is incorporated into an exposed core within the ring body and the dapivirine in the sheath. In this way, in vitro release of dapivirine matches closely that for Ring-004. Also, we report the pharmacokinetic testing of this combination ring formulation in sheep, where vaginal concentrations of both drugs are maintained over 28 days at levels potentially useful for preventing HIV infection in women.

\section{Keywords}

HIV microbicide; Silicone elastomer; Sheep pharmacokinetics; Antiretroviral; Combination drug delivery; HIV prevention 


\section{Introduction}

The past fifteen years have witnessed a resurgence of interest in vaginal ring technologies for drug delivery applications, mostly driven by the impetus for development of vaginallyadministered antiretroviral microbicides to help reduce the high acquisition rates for human immunodeficiency virus (HIV) among Sub-Saharan African women (Malcolm et al., 2015; Notario-Pérez et al., 2017; Thurman et al., 2013; Traore et al., 2018). In 2016, the results of two parallel Phase III clinical studies conducted across multiple sites in Africa were reported for the lead candidate microbicide product, a matrix-type silicone elastomer vaginal ring offering 28-day continuous release of the non-nucleoside reverse transcriptase inhibitor dapivirine (Baeten et al., 2016; Chen et al., 2018). Both clinical studies found that the monthly dapivirine ring helped reduce women's HIV risk by approximately $30 \%$ overall and was welltolerated with long-term use. HIV risk was cut by $45 \%$ among participants who used the ring at least some of the time, and by more than $60 \%$ among women 25 years of age or older. As of early 2019, the developer of the ring, The International Partnership for Microbicides (IPM), is pursuing approvals from regulatory authorities to license the product in countries where women face the highest risk of HIV infection.

Since their conception back in the late 1960s, vaginal rings have relied primarily upon a permeation-controlled drug release mechanism, involving simple molecular diffusion of dissolved drug molecules driven by the drug concentration gradient established between the ring and the vaginal fluid/tissue (Malcolm et al., 2003). For the various silicone elastomer vaginal ring products that have reached market (Estring $₫$, Femring $₫$, Progering $₫$, Fertiring $($ and Annovera $($ ) ) and the dapivirine ring, the drug material is incorporated into the ring matrix or the ring core significantly above its solubility limit at room temperature, such that a sizeable fraction of the drug is present as a dispersed solid in the silicone elastomer. By comparison, for the marketed thermoplastic vaginal ring products Nuvaring® 
and Ornibel $\AA$, the drugs are incorporated into the rings such that they are fully dissolved in the polymeric matrix at room temperature and control of release is achieved using a thermoplastic rate-controlling membrane.

For all of these marketed rings, the reliance on a simple drug permeation mechanism, coupled with the hydrophobic nature of the polymers used for vaginal ring fabrication (e.g. silicone elastomer, ethylene-vinyl acetate copolymer, and thermoplastic urethanes), has generally limited vaginal rings to release of highly potent, relatively hydrophobic, small molecule drugs (McBride et al., 2019). However, recent advances in vaginal ring technology are extending the type of molecules that can be effectively released, as discussed in detail in a recent review article (Malcolm et al., 2015). Recently, we reported a new 'exposed-core' vaginal ring design offering sustained releasing of 5P12-RANTES, a protein-based antiretroviral molecule that targets the CCR5 co-receptor involved in the HIV entry process (McBride et al., 2019).

There is now considerable interest in developing second generation ring products that bring additional clinical benefits. These products could contain combinations of microbicides (to increase the breath of protection against HIV by targeting different steps in the HIV replication cycle and/or to reduce the possibility of emergence of resistant strains of the virus) or different combinations of antiretrovirals, contraceptives agents and/or other agents to treat other sexually transmitted diseases (so-called multi-purpose prevention technologies; MPTs) (Q. Abdool Karim et al., 2014; S. Abdool Karim et al., 2014; Boonstra et al., 2014; Brady and Manning, 2013; Fernández-Romero et al., 2015; Friend et al., 2013; Guilamo-Ramos et al., 2018; Malcolm et al., 2014). Combination vaginal rings containing dapivirine and either maraviroc or darunavir have previously been reported (Chen et al., 2015; Susan M. Fetherston et al., 2013; Murphy et al., 2018, 2014). Maraviroc is an established antiretroviral used in HIV treatment that inhibits entry of HIV into host cells by targeting the CCR5 receptor (Chen et al., 
2015; Susan M. Fetherston et al., 2013); darunavir is a protease inhibitor already used in combination with other antiretrovirals in the treatment of HIV infection (Mallolas, n.d.). Other combination microbicide vaginal rings have also been reported, including dapivirine and tenofovir (Johnson et al., 2010), tenofovir disoproxil fumarate and maraviroc (Moss et al., 2016), MIV-150 and zinc acetate (plus other drugs) (Ugaonkar et al., 2015), and tenofovir, nevirapine, and saquinavir (plus other drugs) (Moss et al., 2013).

In this paper, we report for the first time an exposed core-type vaginal ring device offering simultaneous release of dapivirine and 5P12-RANTES, as demonstrated through in vitro data and a pharmacokinetic study in sheep.

\section{Materials and Methods}

\subsection{Ethics}

The study was carried out in compliance with applicable sections of the United Kingdom Animals (Scientific Procedures) Act 1986, Amendment Regulations 2012. The study complied with the applicable sections of the Codes of Practice for the Housing and Care of Animals used in Scientific Procedures and the Humane Killing of Animals under Schedule 1 of the Act.

\subsection{Materials}

5P12-RANTES (molecular weight: $7904.8 \mathrm{~g} / \mathrm{mol}$ ) solution (cGMP grade; $6.4 \mathrm{mg} / \mathrm{mL}$ in $1.7 \mathrm{mM}$ acetic acid; $\mathrm{pH}$ 4.0) was supplied to Queen's University Belfast by the Mintaka Foundation for Medical Research, Geneva Switzerland (Cerini et al., 2016). 120 kDa molecular weight hydroxypropylmethylcellulose (HPMC), Tween80, acetonitrile and trifluoroacetic acid (TFA) were purchased from Sigma-Aldrich (UK). DDU-4320 silicone liquid rubber was obtained from Nusil Technology (Carpinteria, CA, USA), and dapivirine (DPV) was kindly supplied by IPM (Silver Springs, MD, USA). 


\subsection{Freeze-drying of 5P12-RANTES}

5P12-RANTES solution was freeze-dried to produce a lyophilised powder, following a previously reported method (McBride et al., 2019, 2017). Briefly, 5P12-RANTES was aliquoted into flat bottomed glass petri dishes (diameter $200 \mathrm{~mm}$ ) and freeze-dried (AdVantage Pro BenchTop Freeze Dryer, VirTis, Gardiner, NY, USA) using the following parameters: 5 to $-40^{\circ} \mathrm{C}$ ramp for $1 \mathrm{~h}$ followed by an additional freeze for $2 \mathrm{~h}$. The condenser was then set to $-50^{\circ} \mathrm{C}$ and a chamber pressure of $50 \mathrm{mTorr}$. Shelf temperature was raised to $20^{\circ} \mathrm{C}$ over $27 \mathrm{~h}$, with a coinciding increase in chamber pressure from 120-190 mTorr.

\subsection{Vaginal ring manufacture}

Various designs of exposed-core silicone elastomer vaginal rings (Figure 1) - containing dapivirine alone, dapivirine in the sheath and a drug-free core, or dapivirine in the sheath and HPMC/lyophilised 5P12-RANTES in the core - were manufactured using a laboratory-scale injection molding machine fitted with custom mold assemblies. Dapivirine-only rings were monolithic devices manufactured by single-shot injection. For rings with a blank core or a lyophilised 5P12-RANTES/HPMC (1/4- or full-length core; $4.2 \mathrm{~mm}$ cross-sectional diameter) the core was first manufactured via injection moulding before overmolding with a dapivirinecontaining silicone elastomer to produce a sheath. For the 5P12-RANTES/HPMC core, Part A and Part B DDU-4320 silicone elastomer premixes containing 8.58\% w/w 5P12-RANTES and $21.25 \% \mathrm{w} / \mathrm{w} 120 \mathrm{kDa}$ HPMC were prepared by adding weighed quantities of the powdered materials into screw-cap polypropylene containers, followed by addition of the silicone elastomer parts, and then mixed using a Dual Asymmetric Centrifuge (DAC) mixer (30 s, 3000 rpm; SpeedMixer ${ }^{\mathrm{TM}}$ DAC 150 FVZ-K, Hauschild, Germany). A and B premixes were then combined in a 1:1 ratio, by adding equal weights of each premix to a screw-cap polypropylene container to a final batch weight, hand-mixing for $30 \mathrm{~s}$, and finally DAC mixing (15 s at 1500 
rpm). The active mix was transferred to a 75 g polypropylene SEMCO injection cartridge designed for use with the SEMCO Model-850 injection system. The material was injected into temperature-controlled molds fitted to the injection molding machine and cured for $3 \mathrm{~min}$ at $85^{\circ} \mathrm{C}$. The resulting 5P12-RANTES-loaded cores were subsequently overmolded with dapivirine loaded DDU-4320 silicone elastomer membrane in a second injection molding step, using a custom mold assembly, designed to introduce two large windows in the sheath (Figure $1 \mathrm{G}-\mathrm{H}$ ). To account for differences in ring mass, elastomer mixes having different dapivirine concentrations were prepared. For rings D-F (Figure 1), $0.345 \% \mathrm{w} / \mathrm{w}$ dapivirine was used, the same loading as for production of matrix-type ring A. Matrix ring B and the sheath for device $\mathrm{C}$ contained an increased quantity of dapivirine $(0.367 \% \mathrm{w} / \mathrm{w})$ to account for the reduced ring mass caused by the recesses/indentations on the ring surfaces. After injection molding, rings were subsequently demolded, deflashed and stored at ambient temperature until further testing.

\subsection{Physical characterization and mechanical testing of rings}

Batches of rings were manufactured for mechanical testing. The force required to compress ring devices by $5 \mathrm{~mm}$ was measured using a TA texture analyser (TA-XTPlus, Stable Microsystems, UK), fitted with a $30 \mathrm{~kg}$ load cell and Texture Exponent (TEE32) 32 software, using a custom ring holder. The rings were tested in three different orientations due to the asymmetric nature of their designs, with core inserts being either at the top, side or base during each test. The percentage elastic recovery of rings was measured after compression to $25 \pm 5 \%$ of their original outer diameter (OD) either statically for 28-days or after 1000cyclical compressions. The mechanical test methods are described in detail elsewhere (McCoy et al., 2019). 
For in vitro release testing, rings were individually placed in glass flasks containing release medium $(0.2 \%$ Tween $囚 80$ solution $)$ sampled periodically prior to complete volume replacement. On day 0 and days when sampling did not occur on two consecutive days, 200 $\mathrm{mL}$ of release media was used. On days where sampling took place the following day, $100 \mathrm{~mL}$ was used. For 5P12-RANTES release, rings were placed in $15 \mathrm{~mL}$ of Type 1 water (Millipore Direct-Q 3 UV Ultrapure Water System, Watford, UK) in polypropylene containers (Synergy Devices Limited, United Kingdom) and sampling occurred periodically with complete volume replacement. All flasks containing rings were placed in an orbital shaking incubator $\left(37^{\circ} \mathrm{C}, 60\right.$ rpm, $25 \mathrm{~mm}$ orbital throw). Samples of release medium were stored at $4^{\circ} \mathrm{C}$ and the concentrations of dapivirine and 5P12-RANTES measured using HPLC.

\subsection{Quantification of dapivirine and 5P12-RANTES using HPLC}

Dapivirine and 5P12-RANTES concentrations in in vitro release samples were measured using a Waters Alliance e2695 HPLC and UV 2489 detector (Waters, Dublin, Ireland) with Empower data handling software. Dapivirine quantification was performed using a Thermo Fisher Hypersil BDS ( $3 \mu \mathrm{m}, \mathrm{C18}, 150 \times 4 \mathrm{~mm})$ column and $25 \mu \mathrm{L}$ injection volume. The run was performed under isocratic conditions using phosphate buffer (7.7 mM, pH3) and acetonitrile (55:45) with a $25^{\circ} \mathrm{C}$ column temperature and a $240 \mathrm{~nm}$ wavelength. 5P12-RANTES analysis was performed using $100 \mu \mathrm{L}$ injection volumes, a gradient method comprising mobile phases; A $(0.1 \%$ TFA in water $)$, B (0.0955\% TFA/30\% acetonitrile in water $)$ and C $(0.085 \% \mathrm{TFA} / 95 \%$ acetonitrile in water), $37^{\circ} \mathrm{C}$ column temperature, $280 \mathrm{~nm}$ wavelength and an ACE C8 column (ACE $3 \mu \mathrm{m}, \mathrm{C} 8,300 \AA, 150 \times 4.6 \mathrm{~mm}$, Aberdeen, UK). A flow rate of $1.0 \mathrm{~mL} / \mathrm{min}$ was used throughout.

\subsection{Pharmacokinetic evaluation of 5P12-RANTES and dapivirine combination vaginal ring in} sheep 
An exposed core-type vaginal ring (Figure 1F) containing $63.5 \mathrm{mg}$ 5P12-RANTES in the core and $22.39 \mathrm{mg}$ dapivirine in the sheath was evaluated for pharmacokinetics in Suffolk Cross sheep (36-37 months; 63.0-95.0 kg) at Envigo (Huntingdon, UK). Vaginal fluid, vaginal tissue and serum concentrations of 5P12-RANTES and dapivirine were measured during 28-day ring use. Sheep were housed in indoor pens with wheat straw bedding, and provided with natural light supplemented with overhead fluorescent lighting as necessary and full fresh air. The animals grazed on ewe and lamb pencil pelleted diet, were provided good-quality meadow hay ad libitum, and had an unrestricted water supply. A single group of four sheep was used in this study in which vaginal fluid, tissue and biopsies were sampled periodically for measurement of 5P12-RANTES and dapivirine concentrations. On day 1 of the study, each animal was restrained in a comfortable standing position and the test ring inserted carefully into the cranial vagina using a gloved finger and a small amount of medical-grade lubricant gel as appropriate. Strings (medical-grade monofilament suture material) were fitted to the rings before application and the ends of the tapes left hanging outside the vagina after application. These strings served as an external visual check that the ring was still in place and had not been expelled, and aided retrieval of rings at the end of the study period.

Blood (drawn from the jugular vein) and vaginal fluid (via Weck-Cel sponge) were sampled at the following timepoints: pre-dose, 4 and $24 \mathrm{hr}, 2,4,7,14,21,28$ and 35 days post ring insertion. Vaginal tissue biopsy specimens ( $5 \mathrm{~mm}$ diameter) were sampled on day 7, 21 and 35 post ring insertion from the dorsal aspect of the vagina under local anaesthetic. Collection, processing and analysis of all samples for quantification of 5P12-RANTES in vaginal blood, fluid and tissue were performed using a human CCL5/RANTES ELISA kit, according to methods reported previously (McBride et al., 2019, 2017). 
Dapivirine was measured using a liquid chromatographic-tandem mass spectroscopic method (LC-MS/MS). Briefly, vaginal tissue biopsies and fluid samples (Weck-Cel sponge) and tissue samples were pre-treated with methanol/water/formic acid (50:50:1, v/v/v). Subsequently, HPLC was performed using a Kinetex Phenyl-Hexyl (1.7 $\mu \mathrm{m}, 50$ x $2.1 \mathrm{~mm})$ column, $60^{\circ} \mathrm{C}$ column temperature, and a $250 \mu \mathrm{L}$ injection volume, under a gradient of water: formic acid: 1M ammonium formate (100:0.2:0.2) and acetonitrile/formic acid/1M ammonium formate (100:0.2:0.2). Mass spectrometry was performed using a Symbiosis $6500+$ and electrospray (ESI) ionisation, with a source temperature of $600^{\circ} \mathrm{C}$, and an ion spray voltage of $5200 \mathrm{~V}$. Clinical condition, body weight, and food consumption were recorded during the study.

\section{Results and Discussion}

All ring variants were manufactured successfully, with no gross defects observed and the strong chemical bond between the silicone core and sheath components was not affected by the core excipients.

The force required to compress the rings through $5 \mathrm{~mm}$ was $\sim 0.12 \mathrm{~N}$, and no significant differences in compressional force were observed between the various formulations (Figure 2). Following the cyclical compression test, all ring devices showed recovery to $100 \%$ of the original OD, indicating that the presence of a core, either blank or placebo, or indentations in the outer surface of the ring did not affect their elastic recovery. A similar trend was observed in the static 28 compression results, where all but the ring A showed a recovery between 90$100 \%$ of original diameter.

\subsection{In vitro release}


Cumulative dapivirine in vitro release vs. time plots are presented in Fig. 3 for rings A-E. Drug release from rings $\mathrm{A}, \mathrm{D}$ and $\mathrm{E}$ (matrix ring, matrix ring with two indentations, and matrix ring with a non-medicated core, respectively, Figure 1) was similar, with a total of $\sim 3.2 \mathrm{mg}$ released over the 35-day study. By comparison, a 16\% increase in cumulative dapivirine release was obtained with rings $\mathrm{B}$ and $\mathrm{C}$, attributed to the increased surface area afforded by the 24 small windows (Table 1). In general, dapivirine release is minimally affected by the inclusion of a non-medicated core, despite this resulting in a reduction in total dapivirine content in the ring (Table 1), as evidenced by comparing dapivirine release from rings $\mathrm{B}$ and C. Dapivirine loading in C is reduced by $\sim 40 \%$ compared to ring $B$, and yet dapivirine release is similar, demonstrating that the $\sim 4 \mathrm{mg}$, or $16 \%$, of dapivirine that is released from a $25 \mathrm{mg}$ torus matrix-type ring is due to drug located nearest the external surface of the device.(Spence et al., 2016) Therefore, blank cores may be a useful strategy for reducing drug loading, thereby reducing costs and wastage. Dapivirine release across the various ring designs is related to external surface area of the DPV loaded component of the ring. For example, while rings D and E showed similar dapivirine release to Ring A (with surface areas $103 \%$ or $97 \%$, respectively, relative to ring A), rings B and C showed a significant increase in dapivirine release due to increased surface area (12\% compared to ring A).

The in vitro release characteristics of combination ring $\mathrm{F}$, containing a 5P12-RANTES loaded 1/4-core and a dapivirine-loaded sheath, are presented in Fig. 4. 1.18 mg 5P12-RANTES was released over 28-days rates were similar to previous studies involving $1 / 4$-core rings with a non-medicated sheath (McBride et al., 2019). Dapivirine release was entirely similar to that measured for ring E (Figure 3).

\subsection{Pharmacokinetics}


Previously, we have reported the pharmacokinetics of 5P12-RANTES in sheep following vaginal administration of a 5P12-RANTES aqueous gel formulation and a 5P12-RANTES vaginal ring (McBride et al., 2019, 2017). Also, Holt et al., have previously reported the pharmacokinetics in sheep of the $25 \mathrm{mg}$ dapivirine-releasing vaginal ring (Dapivirine Vaginal Ring-004) (Holt et al., 2015). The sheep model is particularly useful for pharmacokinetic testing of vaginal rings, since, unlike macaques, sheep can be fitted with the same size of ring used in women. Also, the sheep vagina is generally similar in anatomy, physiology and dimensions to that of women, although $\mathrm{pH}$ in sheep is near neutral compared to $\sim 4.5 \mathrm{in}$ healthy reproductive-age women, and sheep have an estrus cycle rather than a menstrual cycle (Ravel et al., 2011; Swartz et al., 2014).

Here, for the first time, we describe the pharmacokinetics in sheep of a novel combinationtype vaginal ring releasing both 5P12-RANTES and dapivirine. This new combination ring design differs from the $25 \mathrm{mg}$ dapivirine-releasing vaginal ring in two ways: first, the ring comprises a central core containing the 5P12-RANTES and other excipients; and second, the dapivirine is located only within a thin sheath layer that partly exposes the underlying 5P12RANTES core. By comparison, in the $25 \mathrm{mg}$ dapivirine-releasing vaginal ring, dapivirine is dispersed throughout the entire ring matrix. However, in clinical studies, only $\sim 4 \mathrm{mg}$ of the initial $25 \mathrm{mg}$ dapivirine is released over 28 days, based on measurement of residual dapivirine in the ring following use (Spence et al., 2016). This $\sim 4$ mg quantity of dapivirine is released from those layers closest to the surface of ring for which the drug diffusion pathway is shortest, in accordance with well-established theory (Malcolm et al., 2003) and evidenced by the visual appearance of a drug depletion zone in the cross-sections of used matrix-type rings (Susan M Fetherston et al., 2013). For this reason, we hypothesized that the absence of dapivirine from the central compartment of a ring (and even the inclusion of a central core containing additional substances, such as 5P12-RANTES and various excipients) would have 
no impact on dapivirine pharmacokinetics, assuming a minimum thickness for the dapivirinecontaining sheath. Moreover, we also anticipated that the presence of dapivirine in the sheath layer would not impact the pharmacokinetics of 5P12-RANTES since it is released from the central core through the exposure window in the sheath.

\subsection{Vaginal fluid}

Quantifiable concentrations of both dapivirine and 5P12-RANTES were observed in all sheep vaginal fluid samples over the 28-day period of ring use, with values for both drugs mostly maintained within the range $10^{2}-10^{4} \mathrm{ng} / \mathrm{g}$ (Figure $5 \mathrm{~A}$ ). On Day 35 , seven days after ring removal, dapivirine concentrations in vaginal fluid had decreased to $\sim 1 \mathrm{ng} / \mathrm{g}$, while 5P12RANTES was undetectable. Mean maximum vaginal fluid concentrations $\left(C_{\max }\right)$ of 5P12RANTES and dapivirine and the mean areas under the vaginal fluid concentration-time curves estimated up to 35 days after ring insertion $\left(A U C_{0-35}\right)$ are summarized in Table 2.

\subsection{Vaginal tissue}

Quantifiable concentrations of both dapivirine and 5P12-RANTES were observed in all sheep vaginal tissue samples measured on Days 7 and 21 post ring insertion (Figure 5B). Dapivirine concentrations in tissue were very similar for the two sampling timepoints during ring use, generally ranging from $1400-4200 \mathrm{ng} / \mathrm{g}$ before decreasing to mean value of $2.14 \pm 2.08 \mathrm{ng} / \mathrm{g}$ seven days after ring removal on Day 35. 5P12-RANTES concentrations were also similar for the two tissue sampling timepoints, although two orders of magnitude lower (range 16.8$108.0 \mathrm{ng} / \mathrm{g}$ ) than those measured for dapivirine. 5P12-RANTES concentrations were below the level of quantification on Day 35 (Figure 5B).

\subsection{Plasma}


Plasma concentrations of 5P12-RANTES were below the limit of quantification $(<70.4 \mathrm{pg} / \mathrm{mL})$ in all samples indicating that there was no systemic exposure. Mean $( \pm S D)$ maximum plasma concentrations $\left(C_{\max }\right)$ of dapivirine were $94.7 \mathrm{pg} / \mathrm{mL}( \pm 10.9)$ and the mean $( \pm \mathrm{SD})$ areas under the plasma dapivirine concentration-time curves estimated up to 35 days after ring insertion $\left(A U C_{0-35}\right)$ were 2050 pg.day/mL $( \pm 350)$ (Table 2$)$.

Overall, the sheep pharmacokinetic data for 5P12-RANTES with this new combination ring are broadly similar to those reported previously for the $1 / 4$-core, two-window, vaginal ring in which the silicone elastomer core containing $8.58 \% \mathrm{w} / \mathrm{w}$ freeze-dried 5P12-RANTES and 17.2\% w/w 120 kDa HPMC (McBride et al., 2019). In this study, the mean vaginal fluid levels for 5P12-RANTES (Figure 5A) are maintained within a narrower range $\left(10^{2}-10^{4} \mathrm{ng} / \mathrm{g}\right.$ ) than those in the previous study $\left(10^{1}-10^{4} \mathrm{ng} / \mathrm{g}\right)$, which is likely the result of an enhanced sustained release effect due to the higher concentration of HPMC in the 5P12-RANTES core $(21.25 \%$ vs 17.2\%). Entirely similar observations apply to the measured vaginal fluid concentrations of 5P12-RANTES; at Day 7, mean values are slightly (but not significantly) higher for the combination ring compared to the 5P12-RANTES only ring. Consistent across both studies is the absence of 5P12-RANTES in the systemic compartment.

Several papers have previously reported pharmacokinetic data for the $25 \mathrm{mg}$ matrix-type dapivirine ring (Ring-004), either in sheep or in women (Chen et al., 2018; Holt et al., 2015; A. Nel et al., 2014; A. M. Nel et al., 2014). In general, dapivirine concentrations in women are significantly higher than those measured in this sheep study, by a factor of approximately six for plasma levels, and by a factor of approximately 50 for vaginal fluid levels, based on Day 28 values reported in Chen et al (Chen et al., 2018).

\section{Conclusions}


This easy-to-manufacture combination microbicide vaginal ring, containing lyophilized 5P12RANTES loaded into an excipient-modified silicone elastomer core and dapivirine incorporated into the silicone elastomer sheath, provided in vitro and in vivo sustained release of both antiretrovirals. Given their different mechanisms of action, this ring device may provide increased protection from HIV infection and limit the emergence of resistant HIV strains. The ring design may also be useful for other drug combinations, particularly were the physicochemical properties of the drugs are very different and need be formulated within discrete components. For example, incorporating a contraceptive hormone into a second non-exposed 1/4-core component (to provide a constant drug release rate) would present a novel multipurpose prevention technology (MPT).

\section{Declaration of Interest}

The authors declare no competing financial or personal interest.

\section{Author Contribution Statement}

P.B. and R.K.M were the principal investigators on the project. Each of the authors contributed to experimental design and analysis of the data. J.W.M. and staff at Envigo conducted the majority of the experimental work while P.B. was responsible for vaginal ring and tooling designs. V.L.K. provided freeze-drying expertise and aided in the lyophilization of the 5P12RANTES. O.H. and R.E.O. helped develop the HPLC methods for quantification of 5P12RANTES. The manuscript was drafted by R.K.M., J.W.M, B.D and P.B. All authors provided input and review which further developed the manuscript. 


\section{Author contributions}

P.B. and R.K.M were the principal investigators on the project. Each of the authors contributed to experimental design and analysis of the data. J.W.M. and staff at Envigo conducted the majority of the experimental work while P.B. was responsible for vaginal ring and tooling designs. V.L.K. provided freeze-drying expertise and aided in the lyophilization of the 5P12RANTES. O.H. and R.E.O. helped develop the HPLC methods for quantification of 5P12RANTES. The manuscript was drafted by R.K.M., J.W.M, B.D and P.B. All authors provided input and review which further developed the manuscript.

\section{Acknowledgments}

This study was partly funded by a research project entitled 'Chemokine-Based Microbicides: A Pathway from a First-in-Human Study toward Phase 2/3 and Licensure', funded by the Wellcome Trust, UK (Grant ID Number: 104252), and by a Confidence in Concept grant awarded to Queen's University Belfast by the Medical Research Council (MRC) UK. The views expressed in this publication are those of the authors and not necessarily those of the Wellcome Trust or the MRC. Dapivirine was supplied by the International Partnership for Microbicides (IPM), which receives generous support from the Danish Ministry of Foreign Affairs, Flanders Department of Foreign Affairs, Irish Aid, the German Federal Ministry of Education and Research (BMBF) through the KfW Development Bank, the Ministry of Foreign Affairs of the Netherlands, UK aid from the British people, the American people through the United States Agency for International Development (USAID) in partnership with the US President's Emergency Plan for AIDS Relief (PEPFAR), and the Bill \& Melinda Gates Foundation. 


\section{Conflict of interest}

The authors declare no competing financial interest. 


\section{Figure \& Table Captions}

Fig. 1. Six different vaginal ring designs. A - Conventional matrix ring. B - Matrix ring with indentations. C - Drug loaded sheath layer with a non-medicated core. D - Drug loaded matrix ring with two indentations. E - Drug loaded matrix ring with a non-medicated 1/4-core. F Dapivirine loaded matrix ring with a 5P12-RANTES 1/4-core. G - Diagrammatic, plan view of ring comprising dapivirine loaded sheath layer (white) with 5P12-RANTES 1/4-core (red). H Cross sectional view of $\mathrm{G}$, sectioned through the 5P12-RANTES $1 / 4$ core, detailing the windows on top and bottom surfaces of the ring. All scale bars $10 \mathrm{~mm}$.

Fig. 2. $0.5 \mathrm{~mm}$ compression testing of vaginal rings. A - conventional matrix ring. B - Matrix ring with indentations. $\mathrm{C}$ - drug loaded sheath layer with a non-medicated core. D - drug loaded matrix ring with two indentations. E - drug loaded matrix ring with a non-medicated 1/4-core. F - dapivirine loaded matrix ring with a 5P12-RANTES 1/4-core. Mean \pm SD; $n=6$.

Fig. 3. Cumulative dapivirine release vs. time profiles for different vaginal ring designs. A Conventional matrix ring. $\mathrm{B}$ - matrix ring with indentations. $\mathrm{C}$ - drug loaded sheath layer with a non-medicated core. D - drug loaded matrix ring with two indentations. E - drug loaded matrix ring with a non-medicated $1 / 4$-core. Samples were incubated in $0.2 \%$ Tween $80,37^{\circ} \mathrm{C}$, throughout the study. Mean $\pm \mathrm{SD} ; \mathrm{n}=3$.

Fig. 4. Mean in vitro cumulative release $(n=3)$ from vaginal rings containing a combination of 5P12-RANTES and dapivirine (Ring code F - dapivirine loaded matrix ring with a 5P12RANTES $1 / 4$-core). One set of rings were incubated in water to assess release of 5P12-RANTES, and another set in $0.2 \%$ Tween80 for dapivirine release. 
Fig. 5. Concentrations of 5P12-RANTES and dapivirine measured in the vaginal fluid (A) and biopsied vaginal tissue (B) of Suffolk Cross sheep during and after 28-day use of vaginal ring $\mathrm{F}$ containing a combination of both drugs (Table 1). Black plot symbols show 5P12-RANTES release from the $1 / 4$-length core, and unfilled plot symbols show dapivirine release from the sheath. Plot symbols represent mean \pm standard deviation of four replicates, except for the Day 35 plot symbol, where $\mathrm{n}=1$ (dapivirine was only detected in one of four animals).

Table 1. Characteristics of vaginal ring formulations containing dapivirine and 5P12-RANTES.

Table 2. Statistical pharmacokinetic parameters for 5P12-RANTES and dapivirine measured in sheep vaginal fluid and vaginal tissue during and after 28-day use of a vaginal ring F (Table 1). $C_{\max }$ and $A U C_{0-\text { last }}$ values are presented as mean $\pm \mathrm{SD}$ of four replicates. $T_{\max }$ values are presented as the medians and ranges of four replicates. 


\section{References}

Abdool Karim, Q., Baxter, C., Abdool Karim, S., 2014. Microbicides and their potential as a catalyst for multipurpose sexual and reproductive health technologies. BJOG 121 Suppl, 53-61. https://doi.org/10.1111/1471-0528.12843

Abdool Karim, S., Baxter, C., Frohlich, J., Abdool Karim, Q., 2014. The need for multipurpose prevention technologies in sub-Saharan Africa. BJOG 121 Suppl, 27-34.

https://doi.org/10.1111/1471-0528.12842

Baeten, J.M., Palanee-Phillips, T., Brown, E.R., Schwartz, K., Soto-Torres, L.E., Govender, V., Mgodi, N.M., Matovu Kiweewa, F., Nair, G., Mhlanga, F., Siva, S., Bekker, L.-G., Jeenarain, N., Gaffoor, Z., Martinson, F., Makanani, B., Pather, A., Naidoo, L., Husnik, M., Richardson, B.A., Parikh, U.M., Mellors, J.W., Marzinke, M.A., Hendrix, C.W., van der Straten, A., Ramjee, G., Chirenje, Z.M., Nakabiito, C., Taha, T.E., Jones, J., Mayo, A., Scheckter, R., Berthiaume, J., Livant, E., Jacobson, C., Ndase, P., White, R., Patterson, K., Germuga, D., Galaska, B., Bunge, K., Singh, D., Szydlo, D.W., Montgomery, E.T., Mensch, B.S., Torjesen, K., Grossman, C.I., Chakhtoura, N., Nel, A., Rosenberg, Z., McGowan, I., Hillier, S., 2016. Use of a Vaginal Ring Containing Dapivirine for HIV-1 Prevention in Women. N. Engl. J. Med. 375, 2121-2132. https://doi.org/10.1056/NEJMoa1506110

Boonstra, H., Barot, S., Lusti-Narasimhan, M., 2014. Making the case for multipurpose prevention technologies: the socio-epidemiological rationale. BJOG 121 Suppl, 23-6. https://doi.org/10.1111/1471-0528.12851

Brady, M., Manning, J., 2013. Lessons from reproductive health to inform multipurpose prevention technologies: Don't reinvent the wheel. Antiviral Res. 100, S25-S31. https://doi.org/10.1016/j.antiviral.2013.09.019

Cerini, F., Gaertner, H., Madden, K., Tolstorukov, I., Brown, S., Laukens, B., Callewaert, N., Harner, J.C., Oommen, A.M., Harms, J.T., Sump, A.R., Sealock, R.C., Peterson, D.J., Johnson, S.K., Abramson, S.B., Meagher, M., Offord, R., Hartley, O., 2016. A scalable low-cost cGMP process for clinical grade production of the HIV inhibitor 5P12-RANTES in Pichia pastoris. Protein Expr. Purif. 119, 1-10. https://doi.org/10.1016/j.pep.2015.10.011

Chen, B.A., Panther, L., Marzinke, M.A., Hendrix, C.W., Hoesley, C.J., van der Straten, A., Husnik, M.M.J., Soto-Torres, L.E., Nel, A., Johnson, S., Richardson-Harman, N., Rabe, L.K., Dezzutti, C.S., Hendrix, C.W., van der Straten, A., Husnik, M.M.J., Soto-Torres, L.E., Nel, A., Johnson, S., Dezzutti, C.S., 2015. Phase 1 Safety, Pharmacokinetics, and Pharmacodynamics of Dapivirine and Maraviroc Vaginal Rings. JAIDS J. Acquir. Immune Defic. Syndr. 1. https://doi.org/10.1097/QAI.0000000000000702

Chen, Beatrice A, Zhang, J., Gundacker, H.M., Hendrix, C.W., Hoesley, Craig J, Salata, Robert A, Dezzutti, C.S., van der Straten, A., Hall, W.B., Jacobson, C.E., Johnson, S., McGowan, I., Nel, A.M., Soto-Torres, L., Marzinke, M.A., Chen, B A, Hoesley, C J, Chen, B A, Salata, R A, 2018. Phase 2a Safety, Pharmacokinetics, and Acceptability of Dapivirine Vaginal Rings in US Postmenopausal Women. Clin. Infect. Dis. 15213, 1-8. https://doi.org/10.1093/cid/ciy654

Fernández-Romero, J.A., Deal, C., Herold, B.C., Schiller, J., Patton, D., Zydowsky, T., Romano, J., Petro, C.D., Narasimhan, M., 2015. Multipurpose prevention technologies: the future of HIV and STI protection. Trends Microbiol. 23, 429-436. https://doi.org/10.1016/j.tim.2015.02.006

Fetherston, Susan M., Boyd, P., McCoy, C.F., McBride, M.C., Edwards, K.-L.L., Ampofo, S., Malcolm, R.K., 2013. A silicone elastomer vaginal ring for HIV prevention containing two microbicides with different mechanisms of action. Eur. J. Pharm. Sci. 48, 406-415. 
https://doi.org/10.1016/j.ejps.2012.12.002

Fetherston, Susan M, Geer, L., Veazey, R.S., Goldman, L., Murphy, D.J., Ketas, T.J., Klasse, P.J., Blois, S., La Colla, P., Moore, J.P., Malcolm, R.K., 2013. Partial protection against multiple RT-SHIV162P3 vaginal challenge of rhesus macaques by a silicone elastomer vaginal ring releasing the NNRTI MC1220. J. Antimicrob. Chemother. 68, 394-403.

https://doi.org/10.1093/jac/dks415

Friend, D.R., Clark, J.T., Kiser, P.F., Clark, M.R., 2013. Multipurpose prevention technologies: Products in development. Antiviral Res. 100, S39-S47. https://doi.org/10.1016/j.antiviral.2013.09.030

Guilamo-Ramos, V., Reading, M., Bowman, A.S., Perlman, D.C., Barrett, S., 2018. Multipurpose Prevention Technologies: A Global Sexual and Reproductive Health Priority. J. Assoc. Nurses AIDS Care 29, 6-9. https://doi.org/10.1016/j.jana.2017.06.003

Holt, J.D.S., Cameron, D., Dias, N., Holding, J., Muntendam, A., Oostebring, F., Dreier, P., Rohan, L., Nuttall, J., 2015. The Sheep as a Model for Preclinical Safety and Pharmacokinetic Evaluations of Candidate Microbicides. Antimicrob. Agents Chemother. AAC.04954-14. https://doi.org/10.1128/AAC.04954-14

Johnson, T.J., Gupta, K.M., Fabian, J., Albright, T.H., Kiser, P.F., 2010. Segmented polyurethane intravaginal rings for the sustained combined delivery of antiretroviral agents dapivirine and tenofovir. Eur. J. Pharm. Sci. 39, 203-212. https://doi.org/10.1016/j.ejps.2009.11.007

Malcolm, K., Woolfson, D., Russell, J., Tallon, P., McAuley, L., Craig, D., 2003. Influence of silicone elastomer solubility and diffusivity on the in vitro release of drugs from intravaginal rings. J. Control. Release 90, 217-225. https://doi.org/10.1016/S01683659(03)00178-0

Malcolm, R.K., Boyd, P.J., McCoy, C.F., Murphy, D.J., 2015. Microbicide vaginal rings: Technological challenges and clinical development. Adv. Drug Deliv. Rev. 103, 33-56. https://doi.org/10.1016/j.addr.2016.01.015

Malcolm, R.K., Lowry, D., Boyd, P., Geer, L., Veazey, R.S., Goldman, L., Klasse, P.J., Shattock, R.J., Moore, J.P., 2014. Pharmacokinetics of a CCR5 inhibitor in rhesus macaques following vaginal, rectal and oral application. J. Antimicrob. Chemother. 69, 1325-1329. https://doi.org/10.1093/jac/dkt506

Mallolas, J., n.d. Darunavir Stands Up as Preferred HIV Protease Inhibitor. AIDS Rev. 19, 105112.

McBride, J.W., Boyd, P., Dias, N., Cameron, D., Offord, R.E., Hartley, O., Kett, V.L., Malcolm, R.K., 2019. Vaginal rings with exposed cores for sustained delivery of the HIV CCR5 inhibitor 5P12-RANTES. J. Control. Release in press, 1-11.

https://doi.org/10.1016/j.jconrel.2019.02.003

McBride, J.W., Dias, N., Cameron, D., Offord, R.E., Hartley, O., Boyd, P., Kett, V.L., Malcolm, R.K., 2017. Pharmacokinetics of the protein microbicide 5P12-RANTES in sheep following single-dose vaginal gel administration. Antimicrob. Agents Chemother. 61, 16-19. https://doi.org/10.1128/AAC.00965-17

McCoy, C.F., Millar, B.G., Murphy, D.J., Blanda, W., Hansraj, B., Devlin, B., Karl Malcolm, R., Boyd, P., 2019. Mechanical testing methods for drug-releasing vaginal rings. Int. J. Pharm. 559, 182-191. https://doi.org/10.1016/J.IJPHARM.2019.01.026

Moss, J. a., Malone, A.M., Smith, T.J., Kennedy, S., Nguyen, C., Vincent, K.L., Motamedi, M., Baum, M.M., 2013. Pharmacokinetics of a multipurpose pod-intravaginal ring simultaneously delivering five drugs in an ovine model. Antimicrob. Agents Chemother. 57, 3994-3997. https://doi.org/10.1128/AAC.00547-13 
Moss, J.A., Butkyavichene, I., Churchman, S.A., Gunawardana, M., Fanter, R., Miller, C.S., Yang, F., Easley, J.T., Marzinke, M.A., Hendrix, C.W., Smith, T.J., Baum, M.M., 2016. Combination pod-intravaginal ring delivers antiretroviral agents for HIV prophylaxis: Pharmacokinetic evaluation in an ovine model. Antimicrob. Agents Chemother. 60, 3759-3766. https://doi.org/10.1128/AAC.00391-16

Murphy, D.J., Desjardins, D., Boyd, P., Dereuddre-Bosquet, N., Stimmer, L., Caldwell, A., Le Grand, R., Kelly, C., van Roey, J., Malcolm, R.K., 2018. Impact of ring size and drug loading on the pharmacokinetics of a combination dapivirine-darunavir vaginal ring in cynomolgus macaques. Int. J. Pharm. 550, 300-308. https://doi.org/10.1016/J.IJPHARM.2018.08.051

Murphy, D.J., Desjardins, D., Dereuddre-Bosquet, N., Brochard, P., Perrot, L., Pruvost, A., Le Grand, R., Lagatie, O., Vanhooren, L., Feyaerts, M., van Roey, J., Malcolm, R.K., 2014. Preclinical development of a combination microbicide vaginal ring containing dapivirine and darunavir. J. Antimicrob. Chemother. 69, 2477-2488. https://doi.org/10.1093/jac/dku160

Nel, A., Haazen, W., Nuttall, J., Romano, J., Rosenberg, Z., van Niekerk, N., 2014. A safety and pharmacokinetic trial assessing delivery of dapivirine from a vaginal ring in healthy women. AIDS 28, 1479-1487. https://doi.org/10.1097/QAD.0000000000000280

Nel, A.M., Haazen, W., Nuttall, J.P., Romano, J.W., Mesquita, P.M.M., Herold, B.C., Rosenberg, Z.F., van Niekerk, N., 2014. Pharmacokinetics and Safety Assessment of Anti-HIV Dapivirine Vaginal Microbicide Rings with Multiple Dosing. J. AIDS Clin. Res. 05, 1000355. https://doi.org/10.4172/2155-6113.1000355

Notario-Pérez, F., Ruiz-Caro, R., Veiga, M.-D., 2017. Historical development of vaginal microbicides to prevent sexual transmission of HIV in women: from past failures to future hopes. Drug Des. Devel. Ther. 11, 1767-1787. https://doi.org/10.2147/DDDT.S133170

Ravel, J., Gajer, P., Abdo, Z., Schneider, G.M., Koenig, S.S.K., McCulle, S.L., Karlebach, S., Gorle, R., Russell, J., Tacket, C.O., Brotman, R.M., Davis, C.C., Ault, K., Peralta, L., Forney, L.J., 2011. Vaginal microbiome of reproductive-age women. Proc. Natl. Acad. Sci. 108, 4680-4687. https://doi.org/10.1073/pnas.1002611107

Spence, P., Nel, A., van Niekerk, N., Derrick, T., Wilder, S., Devlin, B., 2016. Post-use assay of vaginal rings (VRs) as a potential measure of clinical trial adherence. J. Pharm. Biomed. Anal. 125, 94-100. https://doi.org/10.1016/j.jpba.2016.03.023

Swartz, J.D., Lachman, M., Westveer, K., Oâ€TMNeill, T., Geary, T., Kott, R.W., Berardinelli, J.G., Hatfield, P.G., Thomson, J.M., Roberts, A., Yeoman, C.J., 2014. Characterization of the Vaginal Microbiota of Ewes and Cows Reveals a Unique Microbiota with Low Levels of Lactobacilli and Near-Neutral pH. Front. Vet. Sci. 1, 1-10. https://doi.org/10.3389/fvets.2014.00019

Thurman, A., Clark, M., Hurlburt, J., Doncel, G., 2013. Intravaginal rings as delivery systems for microbicides and multipurpose prevention technologies. Int. J. Womens. Health 5, 695. https://doi.org/10.2147/IJWH.S34030

Traore, Y.L., Chen, Y., Ho, E.A., 2018. Current State of Microbicide Development. Clin. Pharmacol. Ther. 104, 1074-1081. https://doi.org/10.1002/cpt.1212

Ugaonkar, S.R., Wesenberg, A., Wilk, J., Seidor, S., Mizenina, O., Kizima, L., Rodriguez, A., Zhang, S., Levendosky, K., Kenney, J., Aravantinou, M., Derby, N., Grasperge, B., Gettie, A., Blanchard, J., Kumar, N., Roberts, K., Robbiani, M., Fernández-Romero, J. a., Zydowsky, T.M., 2015. A novel intravaginal ring to prevent HIV-1, HSV-2, HPV, and unintended pregnancy. J. Control. Release 213, 57-68. https://doi.org/10.1016/j.jconrel.2015.06.018 
Table 1. Characteristics of vaginal ring formulations containing dapivirine and 5P12-RANTES.

\begin{tabular}{lllll}
\hline $\begin{array}{l}\text { Vaginal ring } \\
\text { formulation code }\end{array}$ & $\begin{array}{l}\text { Nominal dapivirine } \\
\text { loading (mg) }\end{array}$ & $\begin{array}{l}\text { Nominal 5P12-RANTES } \\
\text { loading in core (mg) }\end{array}$ & $\begin{array}{l}\text { No. and size of } \\
\text { orifices/windows }\end{array}$ & $\begin{array}{l}\text { External surface } \\
\text { area of DPV part } \\
\left(\mathrm{mm}^{2}\right)\end{array}$ \\
\hline A & 25.0 & - & none & 3780 \\
B & 25.0 & - & $\begin{array}{l}\text { none (24 small } \\
\text { indentations/recesses) }\end{array}$ & 4232 \\
C & 15.5 & - & 24 small orifices & 4232 \\
D & 25.0 & - & none (2 large & 3890 \\
E & 22.4 & - & $\begin{array}{l}\text { indentations/recesses) } \\
\text { 2 large windows }\end{array}$ \\
\hline
\end{tabular}


Table 2. Statistical pharmacokinetic parameters for 5P12-RANTES and dapivirine measured in sheep vaginal fluid and vaginal tissue during and after 28-day use of a vaginal ring F (Table 1). $C_{\max }$ and $A U C_{0 \text {-last }}$ values are presented as mean $\pm \mathrm{SD}$ of four replicates. $T_{\max }$ values are presented as the medians and ranges of four replicates.

\begin{tabular}{|c|c|c|c|c|c|c|c|c|c|}
\hline \multirow[b]{2}{*}{ Drug } & \multicolumn{3}{|l|}{ Plasma } & \multicolumn{3}{|c|}{ Vaginal fluid } & \multicolumn{3}{|c|}{ Vaginal tissue } \\
\hline & $\begin{array}{l}C_{\max } \\
(\mu g / g)\end{array}$ & $\begin{array}{l}T_{\max } \\
\text { (days) }\end{array}$ & $\begin{array}{l}\text { AUC } 0 \text {-last } \\
(\mu \text { g.day } / g)\end{array}$ & $\begin{array}{l}C_{\max } \\
(\mu \mathrm{g} / \mathrm{g})\end{array}$ & $\begin{array}{l}T_{\max } \\
\text { (days) }\end{array}$ & $\begin{array}{l}A U C_{0 \text {-last }} \\
(\mu g . \text { day } / g)\end{array}$ & $\begin{array}{l}C_{\max } \\
(\mathrm{ng} / \mathrm{g})\end{array}$ & $\begin{array}{l}T_{\max } \\
\text { (days) }\end{array}$ & $\begin{array}{l}\text { AUC } C_{0 \text {-last }} \\
(\mu \mathrm{g} \cdot \mathrm{day} / \mathrm{g})\end{array}$ \\
\hline $\begin{array}{l}\text { 5P12- } \\
\text { RANTES }\end{array}$ & $<\mathrm{LOQ}$ & $<\mathrm{LOQ}$ & $<\mathrm{LOQ}$ & $\begin{array}{l}11.2 \pm \\
9.0\end{array}$ & $\begin{array}{l}0.17 \\
0.17- \\
0.17\end{array}$ & $\begin{array}{l}37.3 \pm \\
16.1\end{array}$ & $\begin{array}{l}60.4 \pm \\
32.9\end{array}$ & $\begin{array}{l}14,7- \\
21\end{array}$ & $\begin{array}{l}0.59 \pm \\
0.22\end{array}$ \\
\hline dapivirine & $\begin{array}{l}94.0 \pm \\
10.6\end{array}$ & $\begin{array}{l}2.08, \\
0.167- \\
7\end{array}$ & $1.9 \pm 0.41$ & $\begin{array}{l}5.10 \pm \\
2.8\end{array}$ & $14,0.16-1$ & $\begin{array}{l}62.1 \pm \\
23.2\end{array}$ & $\begin{array}{l}2990 \pm \\
1370\end{array}$ & $\begin{array}{l}14,7- \\
21\end{array}$ & $\begin{array}{l}42.8 \pm \\
27.1\end{array}$ \\
\hline
\end{tabular}



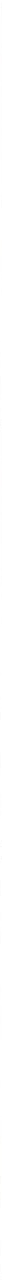

G

$\mathrm{H}$

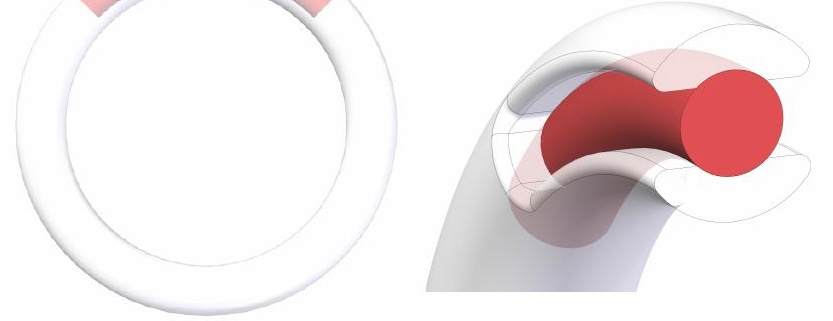




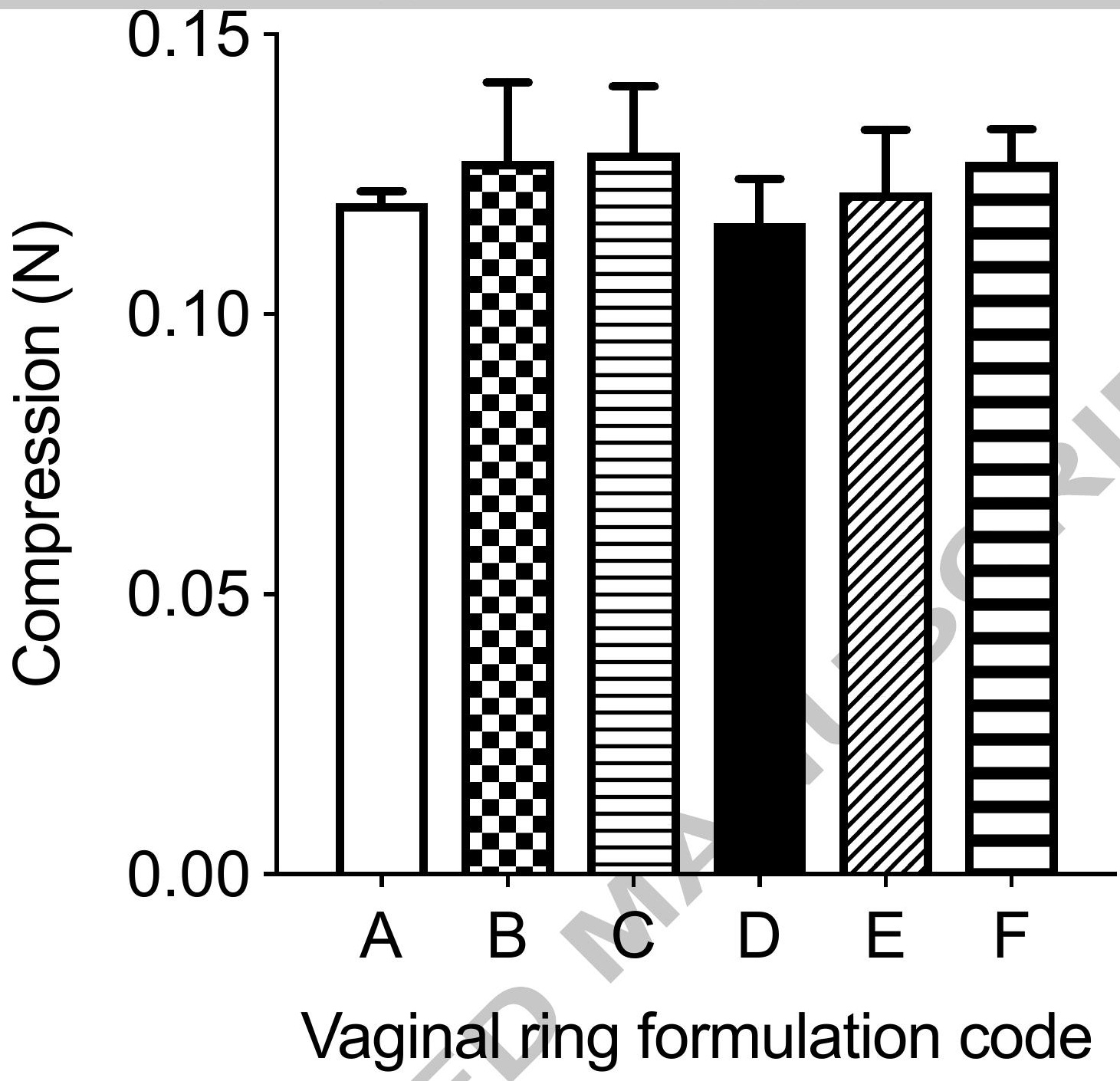


$4^{4000} 1$

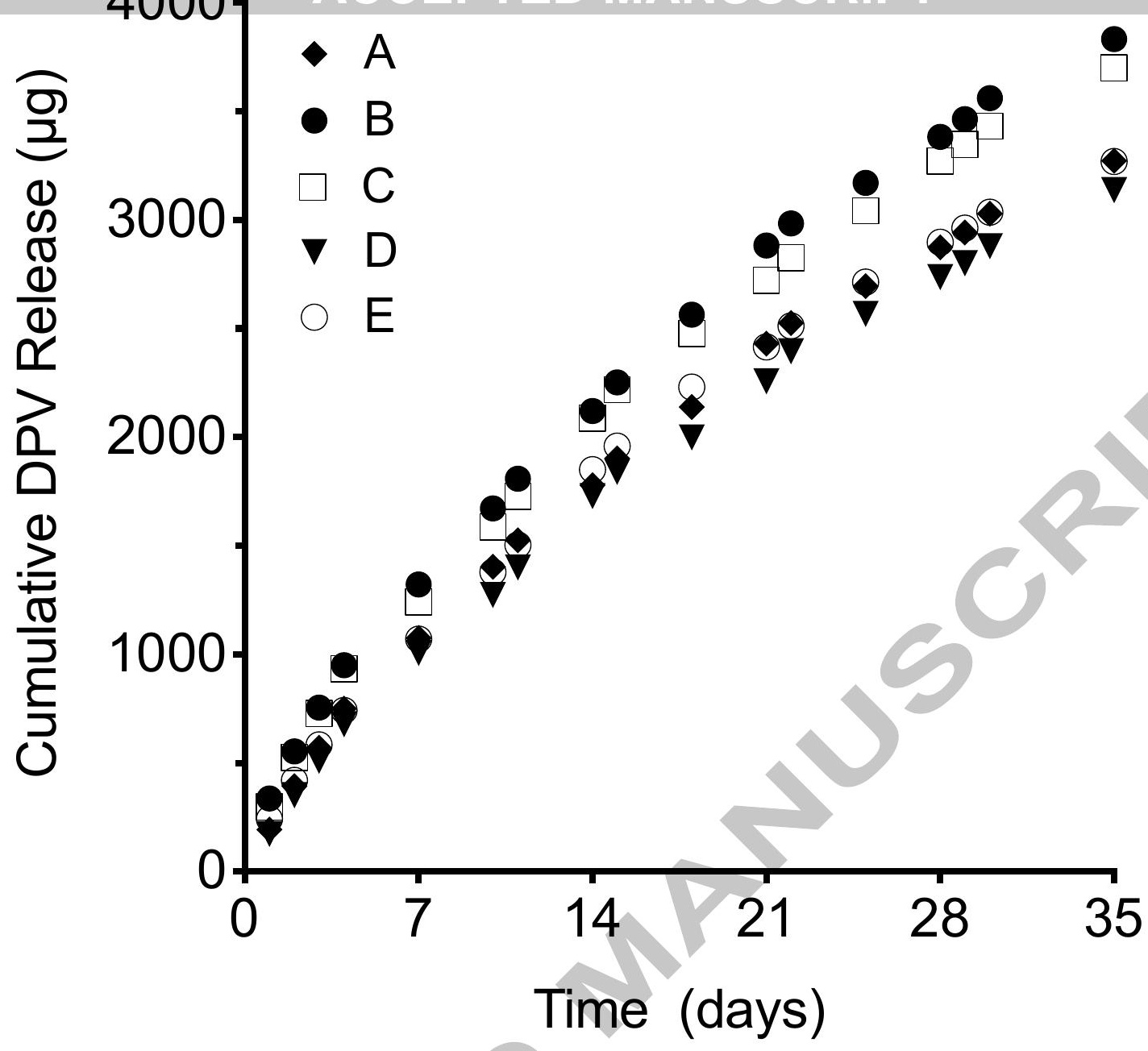




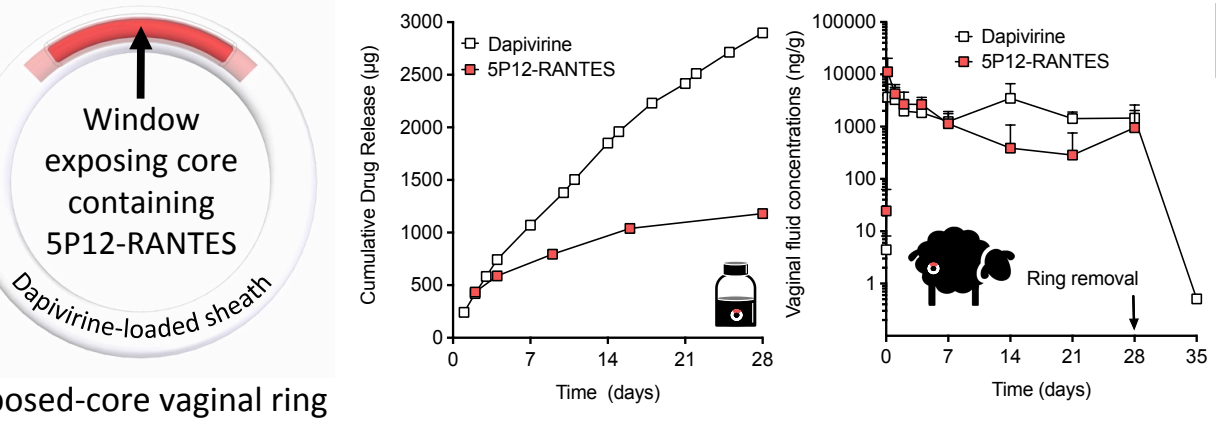

\section{Exposed-core vaginal ring}

